\title{
EL ATRACTIVO ÉTICO DE LA POESÍA DE ÁNGEL GONZÁLEZ: A PROPÓSITO DE ÁSPERO MUNDO
}

\author{
Marta Beatriz FERRARI \\ Universidad Nacional de Mar del Plata \\ martabeatrizferrari@gmail.com
}

\begin{abstract}
[...] el poema y la poesía suelen explicar algunas cosas; en primer lugar, al propio poeta que, más que creador del poema, debe ser considerado su criatura: un subproducto, una excrecencia de las palabras. El poeta no es, en consecuencia, quien escribe el poema, sino el que queda escrito, lo que es leído: su leyenda; una aparición que sólo se materializa en la fantasía del lector. Su existencia es precaria; depende de los otros. El poeta vive en la lectura igual que los fantasmas habitan en el miedo. - Y usted, ¿qué dice que es? -Yo, poeta. - Pues es usted un fantasma.
\end{abstract}

Ángel González, La poesía y sus circunstancias

Han transcurrido 60 años desde la aparición del primer libro de poemas de Ángel González -Áspero mundo, publicado en 1956 - y nuestra propuesta consiste en intentar descifrar los mecanismos que rigen la sostenida vigencia de su voz, abordando su escritura poética desde una perspectiva que podríamos llamar en un sentido amplio "retórica".

Cuando hablamos de "perspectiva retórica" no nos referimos al sentido más restringido de la retórica, el que la reducía a la detección de tropos o figuras (el plano de la elocutio) o a la identificación de moldes formales (el plano de la dispositio); por el contrario, nos referimos al carácter argumentativo del discurso y a las diversas tecnologías de la persuasión. Si bien, durante largo tiempo (quizá desde los siglos XVII y XVIII cuando se impone la Retórica Preceptiva, pero sobre todo en la segunda mitad del XIX con la emergencia de la rebeldía romántica) la disciplina no gozó de muy buena reputación debido a que se había reducido casi exclusivamente a un inventario de fórmulas y definiciones igualmente complejas, ya entrado el siglo XXI, y con los imprescindibles aportes de la llamada "Nueva Retórica" (Perelman y Olbrechts-Tyteca pero también Jakobson, Barthes, Genette y los integrantes del Grupo $\mu$ ), asistimos a la actualización de una Retórica que, como disciplina transversal y multidisciplinaria que es, se muestra con la flexibilidad suficiente como para ser capaz de abordar nuevos objetos al tiempo que se implica en los nuevos medios. Se trata de una retórica no enfocada exclusivamente en la deliberada eficacia del procedimiento, en su componente intencional, sino entendida como parte constitutiva de todo intercambio social donde el hablante por el solo hecho de 
tomar la palabra ya está construyendo un ethos que será el resultante de los estereotipos, los modelos sociales y la doxa o conjunto de opiniones, creencias y representaciones colectivas de una sociedad, adquiriendo un carácter no unidireccional —en el sentido del "hablar dirigido" de Kurt Spang-, sino fundamentalmente dialógico. Efectivamente, desde hace unos 15 años una de las principales nociones retóricas, la de ethos, ha recobrado nuevo impulso y nueva significación de la mano de las teorías -mayoritariamente francesas- de análisis del discurso.

La complejidad del fenómeno de la enunciación en el discurso lírico nos desafía a explorar nuevas vías de aproximación al mismo. Al tratarse de un fenómeno sociodiscursivo unificado (Amossy), que se sitúa en una zona fronteriza entre texto y contexto, entre biografismo y sociologismo, el concepto de ethos retórico (el carácter del hablante poético pero también el ethos autoral) parece ser una categoría potencialmente productiva para el abordaje del tema, al permitirnos una mejor comprensión del hecho literario enmarcado tanto en aspectos discursivos y pragmáticos como institucionales e ideológicos.

El concepto de ethos que nos propone la retórica remite entonces tanto al carácter ético del sujeto que nos habla en el discurso (en nuestro caso en el discurso poético), como también al ethos del autor. Si hacemos un poco de historia, comprobamos que ya Aristóteles definía a la retórica como "la facultad de considerar en cada caso lo que cabe para persuadir" (1971: 10), y señalaba que para lograr un efecto persuasivo sobre el receptor, el orador se servía de tres formas: "unas residen en el carácter del hablante (ethos), otras en poner en cierta disposición al oyente (pathos), otras residen en el mismo discurso (logos)" (1971: 10). Cualquier enunciado, entonces, persuade y convence a su destinatario si sus premisas son racionales y adecuadas (logos), pero también si quien nos lo dice es alguien que conquista nuestra confianza (ethos) sin dejar, al mismo tiempo, de conmovernos (pathos).

En un sentido similar, en la Roma del siglo I, Quintiliano afirmará que la fuerza de la elocuencia es la capacidad del hablante de mover los afectos del oyente, y ejemplifica: "Cuando un juez comienza a enojarse, a favorecer, a aborrecer y a compadecerse, tiene ya por suya nuestra razón" (1916: 224). Para el retórico latino, el ethos y el pathos son dos tipos diferentes de afectos: mientras el primero es un afecto apacible, que persuade al oyente ganándose su benevolencia, el segundo es un afecto fuerte y vehemente que domina y excita el ánimo con fuerza arrebatadora.

En todo acto enunciativo, entonces, un sujeto se dirige a un destinatario y al hacerlo, proyecta una imagen de sí a través de las peculiares modalidades de su decir; el tono y el estilo del discurso tanto como sus competencias lingüísticas o epistémicas comunican un ethos y una visión de mundo particulares, posicionamiento que se resolverá, en última instancia, en proyectos de escritura diversos. Como el orador de la retórica clásica, el sujeto poético se propone conmover al receptor sirviéndose de la fuerza afectiva que posee toda configuración retórica del lenguaje. Un poema, entonces, busca la adhesión de su destinatario utilizando ciertos tópicos y artificios argumentativos -el exordio, la captatio benevolentiae, la cita o el argumento de autoridad, la interrogación retórica- y ciertos recursos menos evidentes, más sutiles pero igualmente poderosos que también conforman el ethos discursivo, y que en muchas ocasiones, responden a la imagen que el autor se forma del auditorio al 
que se dirige, diseñando de este modo un juego especular de imágenes entre ambos polos del intercambio retórico ${ }^{1}$. En este sentido, el crítico catalán Joan Ferraté afirmaba muy tempranamente que las "simpatías y antipatías del lector no pueden tener por base más que la figura que dibuja el propio poema de una voz, una actitud, una situación y una experiencia humanas peculiares, afines o no, atractivas o no" (1968: 359-360).

Pero Aristóteles dice algo más: “A los hombres buenos les creemos de un modo más pleno y con menos vacilación (...). No es verdad que la bondad personal de quien habla no contribuye nada a su poder de persuasión". (1971: 10) Como vemos, él está distinguiendo claramente entre un ethos discursivo (la figura del hablante construida en el discurso) y una imagen extradiscursiva. El ethos autoral será, entonces, la resultante del complejo de imágenes que un autor construye de sí mismo tanto en su escritura de ficción como en los discursos críticos o ensayísticos, en sus entrevistas y epistolarios $^{2}$.

Como señalábamos más arriba, la noción de ethos ha recobrado en las últimas décadas una nueva significación de la mano de las teorías de análisis del discurso. Muy recientemente, me refiero a los años que van entre el 2000 y el 2010, se han dado a conocer múltiples trabajos que se ocupan de describir los tipos de ethos que se construyen y proyectan en el discurso político, académico y periodístico desde perspectivas que entrecruzan el análisis del discurso con los enfoques sociológicos de la literatura. En torno a la figura central de Dominique Maingueneau, lingüista e investigador de la Universidad de la Sorbona, se viene desarrollado una línea de investigación que se puede seguir a través de las numerosas publicaciones de Ruth Amossy y de Jerome Meizoz. Amossy y Maingueneau proponen hablar de un "ethos previo" o de un "ethos prediscursivo" respectivamente, entendiendo por ello la imagen hipotética que el receptor se hace del autor en función de su obra anterior, de su reputación en tanto figura pública, de su posición institucional dentro del campo, de ciertos estereotipos profesionales.

Dentro del campo literario, contamos también con la valiosa aproximación preliminar que realizara en 2005 el crítico catalán Pere Ballart al estudio del ethos en el género lírico. En este escrito titulado "Una elocuencia en cuestión o el ethos contemporáneo del poeta", Ballart señala que "el problema al que se enfrenta el poeta contemporáneo es que su voz ha ido perdiendo credibilidad" (2995: 75), y cita los conocidos versos de Baudelaire — "Hipócrita lector, mi igual, hermano mío"como muestra de esta difícil complicidad entre autor y lector. Ahora bien ¿cómo puede el poeta — se pregunta Ballart - dotar a sus palabras de un permanente atractivo ético? En lo que sigue intentaremos acercar una posible respuesta a este interrogante que no es otro que preguntarnos por cómo Angel

\footnotetext{
${ }^{1}$ Con respecto a los artificios argumentativos, resulta interesante la propuesta que Carlos Mangone y Jorge Warley ofrecen para el análisis de los modos de argumentación de los manfiestos, así como los aportes de Marc Angenot y Eliseo Verón, allí incluidos. (1994: 58-64). Por otra parte, con respecto al carácter especular del intercambio retórico, Craig Smith sostiene que el ethos reside no sólo en el hablante sino también en el oyente y que descubrir las creencias de nuestra audiencia (cuyo ethos varía según la edad, la riqueza, la cuna o el poder) es la clave del éxito de nuestra credibilidad como hablantes (2004: 1-19). En este sentido, podríamos hablar de la naturaleza dialógica del concepto de ethos.

${ }^{2}$ Importa subrayar el concepto de "resultante" aplicado al ethos, en el sentido en que Souriau nos lo explica: como el resultado (siempre posterior) de una operación reflexiva y/o afectiva del lector. (1933: 201)
} 
González logra construir en su poesía una voz convincente y un discurso persuasivo, capaz de ganar nuestro asentimiento como lectores.

Inserta usualmente por la crítica en la promoción de poéticas sociales de los años '50, la obra de Ángel González atraviesa, en rigor, toda la segunda mitad del siglo XX, desde 1956 en que aparece su primer poemario, Aspero mundo, hasta 2008 en que se publica su libro póstumo Nada grave. Con esto quiero subrayar que su escritura poética es coetánea, por una parte, de los sociales del ‘40 (Blas de Otero publica Pido la paz y la palabra en 1955, De claro en claro de Gabriel Celaya es de 1956 y Cuanto sé de mí de José Hierro ve la luz en 1957), por otra, es contemporánea de las estéticas del sesentayocho (Tratado de urbanismo se publica en 1967, el mismo año que La muerte en Beverly Hills, de Pedro Gimferrer), y también, de las propuestas figurativas de los poetas de la experiencia a partir de los años 80 (Prosemas o menos aparece en 1985 coincidiendo con los poemarios centrales de Luis García Montero).

El primer libro de Ángel González - Áspero mundo- es, en palabras de su autor, el resultado de la integración de elementos dispersos, "poemas de amor y viejos sonetos y canciones salvados de la destrucción" (Tino Villanueva, 1988: 120). Sin embargo o precisamente por ello, frente a este declarado carácter inorgánico, hay en el libro una voluntad organizativa muy evidente. Se abre con un poema pórtico definido también por su cuidada arquitectura: dos estrofas de igual número de versos que diseñan un arco que tensiona el vínculo sujeto/mundo, pero también la oposición temporal entre un pasado - el de la posesión de la experiencia: "Te tuve / cuando eras / dulce, / acariciado mundo" (2009: 11) - y un presente donde lo que era posesión se trasmuta en sentimiento y percepción: "percibo tu inequívoca presencia. / ...agrios perfiles, duros meridianos, / ¡áspero mundo para mis dos manos!”. Como vemos, en este poema inicial, emerge ya la doble figuración que dará título a las restantes secciones del libro: "acariciado mundo" y "áspero mundo" (2009: 11).

El ethos o el carácter del hablante en este primer libro de Ángel González se nos muestra a través de una serie de poemas enunciados desde la primera persona del singular. Evidentemente, el dispositivo formal con mayor incidencia en la construcción del ethos es el juego con los pronombres que permiten identificar al responsable de los enunciados, la acusada personalización del discurso poético. Su elección concreta, su mayor o menor recurrencia regulan el acercamiento efectivo al lector. Ruth Amossy ha dedicado varios de sus ensayos al estudio de la inscripción del ethos en el discurso, como modo de vehiculizar una imagen de sí; la investigadora de la Universidad de Tel Aviv retoma las tesis de Dominique Maingueneau y establece una distinción entre el "ethos mostrado" y el "ethos dicho" (2010: 103-130). Efectivamente, el sujeto se muestra tanto en el acto de tomar la palabra, en tanto sujeto de la enunciación, como al hablar de sí mismo, en tanto sujeto del enunciado. El caso más evidente, que entrecruza ambos ethos, es aquel que nos revela la identidad de la voz enunciante y nada mejor para ejemplificar lo que venimos señalando que el poema titulado "Para que yo me llame Ángel González" (2009: 15). Como lectores, la irrupción del nombre propio del autor empírico dentro de la convención poemática juega a favor del efecto persuasivo deseado; en ese intercambio entre el yo que habla y el tú que lee se negocia exitosamente la identidad del hablante. En este poema de clara voluntad 
genesíaca se nos invita en tanto lectores, a remontarnos al remoto origen de ese yo que nos habla, una instancia previa, anterior incluso a la concreción misma del ser de ese sujeto intrínsecamente histórico que sostendrá la enunciación de todo el libro. Pero la conformación de ese ethos elegíaco está, desde su inicio, atravesada por la nota de lo menor; de hecho, llegamos a una definición del mismo cuando ya hemos leído más de la mitad del poema y dicha definición nos llega por vía negativa:

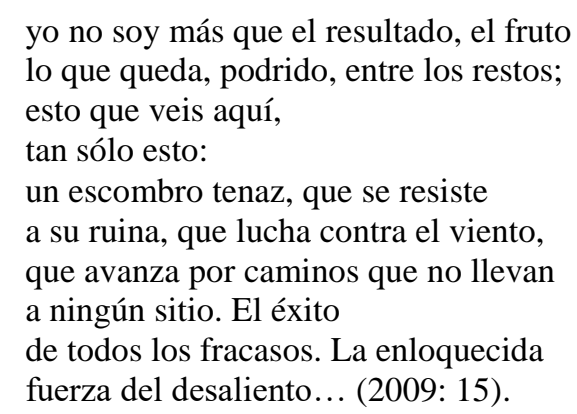

La ubicación cuasi proemial de este texto, al situarse como señala Arturo Casas en "un limen pragmático", vincula al yo poético con "una instancia ficcional intermedia", una especie de "autor implicado" que actúa como carta de presentación del sujeto a la vez que fija y cristaliza el ethos de este hablante (Casas, 2000: 55). La elección de los deícticos 'esto' y 'aquí orientan la lectura del poema hacia la materialidad de la escritura; ellos señalan una presencia, la del sujeto, que sólo se hace evidente a través de las propias marcas escriturales. Al apelar al lector - "esto que véis aquí / tan solo esto"- el texto realiza un gesto autorreflejo que apunta insistentemente a la materialidad física de la grafía que lo constituye habilitando una lectura en clave biográfica al avalar la plena identificación entre sujeto y escritura poética. Mauro Caffarato afirma que éste es el poema más reseñado, leído, comentado y escuchado de González, que ha ejercido una enorme fascinación sobre varias generaciones de lectores y que esto es así "no porque nos haga recordar o tomar conciencia de algo" sino "porque tiene la virtud de incorporarse inevitablemente al lector" (2008: 91).

El impulso humanizador de su escritura se revela asimismo en la ostensible insistencia en el orden de lo humano que advertimos en otros poemas del libro, en los que la reiteración del vocablo 'hombre' subraya significativamente los límites de la estricta humanidad de este sujeto, radicalmente alejado de la figuración hipermagnificada del sujeto poético de la modernidad. En el poema que comienza con los versos "Aquí Madrid, mil novecientos / cincuenta y cuatro" (2009: 16) asistimos a una escritura situada en el 'aquí' y en el 'ahora' que ancla la experiencia subjetiva en la historicidad y subraya obsesivamente los límites de lo humano a través de la reiteración de la lexía 'hombre': “un hombre solo", "un hombre lleno de febrero", "un hombre: un hombre solo", "un hombre con un año para nada".

El propio González se pronuncia muy claramente al respecto en las siguientes declaraciones:

La poesía que me apasiona es la que vierte su luz dentro de las fronteras del reino de los hombres, humilde y menesteroso pero no exento de grandeza y de misterio; poesía que lo ilumina, anuncia y denuncia, afirma y cuestiona; palabra que no silencia la realidad, que no la margina en los espacios blancos de la escritura; palabra cargada de razón, de emoción y de conocimiento, de vida y de experiencia: fe de vida (2005: 474). 
Queda claro, entonces, que la apuesta poética del autor se apropia de los tres componentes básicos que definen el discurso persuasivo: palabra — dirá- cargada de razón (logos), de emoción (pathos), y de vida, conocimiento y experiencia (ethos). Asimismo, estas declaraciones autorales exhiben las virtudes que Quintiliano exigía para que el ethos del hablante fuera efectivo: "ostentar una bondad basada en la ternura y la humanidad" (1916: 131).

La naturaleza del ethos gonzaliano es la provisionalidad, su carácter precario y transitorio como leemos en los versos del poema titulado "Cumpleaños": "Yo lo noto: cómo me voy volviendo / menos cierto, confuso, /disolviéndome en aire / cotidiano, burdo / jirón de mí, deshilachado / y roto por los puños" $(17)^{3}$. La conciencia siempre alerta de la temporalidad constitutiva del yo acompaña este lento proceso que culmina paradójicamente con la disolución y el acabamiento del sujeto: "Todo lo que me unía con la vida / deja de ser unión, se hace distancia, / se aleja más, al fin desaparece, / y muerto soy, / ...y nadie me levanta" (2009: 20). La insistencia en una concepción materialista del yo trabaja en idéntico sentido; el sujeto se observa y se define dentro de los límites de una concepción crasamente material, diríamos incluso fisiológica, un "ser que pesa sobre el suelo", un yo hecho de - y cito los semas gonzalianos - sangre, hueso, piel, músculos, pulso, corazón, desprovista de toda aspiración trascendente.

Este primer libro está, además, saturado de marcas de subjetividad — subjetivemas en términos de Kerbrat Orecchione-, que van desde el empleo privilegiado de la primera persona del singular y las formas pronominales afines, pasando por el uso de signos de exclamación y puntos suspensivos, hasta la decidida elección léxica de verbos, adverbios, sustantivos y adjetivos que comportan una clara carga de subjetividad afectiva, evaluativa o axiológica. "Todos ustedes parecen felices..." es una clara muestra de esto que vengo diciendo; en él, se sanciona una felicidad sólo aparente, la de los otros, denuncia que le sirve al sujeto para oponer el amor al odio, la dicha a la amargura y concluir hablando otra vez de sí mismo: “y hablan / con el fin de ocultar esa amargura / inevitable, y cuántas / veces no lo consiguen, como / no puedo ocultarla / por más tiempo: esta / desesperante, estéril, larga, / ciega desolación por cualquier cosa / que — hacia donde no sé-, lenta, me arrastra” (2009: 25).

Como es dable advertir, la aparición del yo como tema del propio discurso, el "ethos dicho", es una constante en este primer poemario, rasgo que refuerza el carácter declarativo, confesional y autobiográfico que el propio autor atribuyó a su escritura: "Un libro — dirá en una conferencia pronunciada en 1974 - en el que, o vienen poemas vigorosamente autobiográficos o personales, o poemas de tipo más bien estéticos, o poemas juegos" (Villanueva, 1988: 121). El tono confesional

\footnotetext{
${ }^{3}$ Este carácter provisional del sujeto se afilia directamente con el carácter provisional que le asigna a su quehacer literario; muestra de esto son las numerosas "Poéticas" compuestas por el autor en poemarios posteriores. Proceso antes que producto acabado, la escritura, parece decir González, se reduce a ser sólo aproximación, nota colocada al margen de un escrito, "breve acotación" o bien, sólo una parte que sirve para evaluar un todo al que nunca accedemos: la escritura poética es, entonces, una "muestra de". Búsqueda, intento, aproximación, la provisionalidad parece ser el rasgo que mejor define su escritura: primero palabra temporal acechada por la restricción de un silencio obligado, después palabra insuficiente para establecer vínculos sólidos con lo "real", por último, la palabra desprovista de toda aura, la desacralización de la poesía, la antipoesía.
} 
domina tanto la escritura poética como las declaraciones autorales: "Estos poemas desalentados, pesimistas, —dirá en esa misma conferencia - revelaban un estado de ánimo que, les aseguro, no era un pesimismo ni una melancolía literarias. Era una desolación que yo sentía realmente dentro de mí" (Villanueva, 1988: 125). Como vemos, también en sus intervenciones públicas, el autor solicita explícitamente el asentimiento y la complicidad de los oyentes con ese inciso fuertemente apelativo: "les aseguro".

Resulta significativo que de los treinta y ocho poemas que componen Áspero mundo, diecisiete sean retomados, cuarenta años después, en la Antología personal del autor, A todo amor publicada por Visor en 1996. Efectivamente, son muchos los poemas que abordan el tópico amoroso en este primer libro. "Yo sé que existo / porque tú me imaginas", así arranca el poema titulado "Muerte en el olvido" (2009: 21). La razón de amor sustituye en la poética gonzaliana al cógito cartesiano; la única evidencia del existir es el amor del otro, la mirada del otro, el pensamiento del otro: "Soy alto porque tú me crees / alto, y limpio porque tú me miras / con buenos ojos, / con mirada limpia. / Tu pensamiento me hace / inteligente, y en tu sencilla / ternura, yo soy también sencillo / y bondadoso" (2009: 21). Estamos frente a un sujeto vacío que se llena de significado en relación dialéctica con el tú desde una actitud pasiva de predispuesta disponibilidad: "pero si tú me olvidas / quedaré muerto sin que nadie / lo sepa. Verán viva / mi carne, pero será otro hombre / —oscuro, torpe, malo- el que la habita". A medida que recorremos el libro, se va consolidando la figuración de la vacuidad del sujeto, que sólo se llena con la imagen - "la presencia y la figura" de San Juan de la Cruz - de la amada: "mientras nada / me llene el corazón si no es tu imagen", leemos en el poema "Mientras tú existas" (2009: 35). El empleo del participio desvela, una y otra vez, la actitud de pasiva espera del sujeto - "Prendido de un débil sí, / sobre el abismo de un no, / me debato: último / amor"- porque el planteo amoroso adquiere en este poemario dimensiones ontológicas: la ausencia del tú amoroso implica al mismo tiempo la desaparición de toda posibilidad de existencia para el sujeto: “Todo lo llevas con tu cuerpo. / Todo lo llevas. / Me dejas naufragando en esta nada / inmensa” (2009: 34). Como vemos, también la construcción del sujeto amoroso se inserta plenamente dentro de lo menor, del lugar subalterno que es el posicionamiento dominante del ethos íntimo gonzaliano.

Sin embargo, el planteo del tópico amoroso no se limita a estos poemas en los que la figuración del "tú" aparece como término para la definición del "yo"; toda la sección subtitulada "Acariciado mundo" nos propone un ejercicio objetivo de contemplación del paisaje (tanto urbano como natural) en el que irrumpe el "tú" amoroso, y que confina al sujeto al rol de testigo extrañado, desde un registro lírico contenido que recuerda a ciertas escrituras del 27, especialmente a Gerardo Diego y a Pedro Salinas. Como muestra de lo dicho leamos el siguiente poema:

\footnotetext{
Perros contra la luna, lejanísimos,

llevan hasta los ámbitos

más próximos la inquietud de la noche

rumorosa. Claros

sonidos, antes inaudibles,

se perciben ahora. Ecos vagos,

jirones de palabras, goznes
} 
agrios,

desasosiegan el recinto en sombra.

Apenas sin espacio,

el silencio, el inasible

silencio, cercado

por los ruidos, se aprieta

en torno de tus piernas y tus brazos,

asciende levemente a tu cabeza,

y cae por tus cabellos destrenzados.

Es la noche y el sueño: no te inquietes.

El silencio ha crecido como un árbol (2009: 54).

Muchos de los poemas que integran Aspero mundo, leídos retrospectivamente, es decir, desde el conocimiento cabal de la posterior producción poética gonzaliana, resultan llamativamente líricos, más aún teniendo en cuenta lo que sus compañeros generacionales estaban escribiendo en esa misma época. Pero es otra vez su autor quien nos informa acerca del contexto exacto de producción de este libro, “escrito — dirá- en el aislamiento de mi provincia, de mi pueblo natal, Oviedo, sin tomar contacto todavía con los grupos literarios que estaban funcionando en el país". Y agregará: "escrito a partir de experiencias casi de adolescente todavía y con un bagaje de lecturas muy incompletas" (Villanueva, 1988: 120). Como vemos, el ethos autoral proyecta a través de estas declaraciones una preocupación por salvar desde el reconocimiento de dichas "limitaciones" (principalmente el aislamiento cultural) las posibles o, al menos, imaginables reacciones que su libro pudo llegar a generar ${ }^{4}$.

De todos modos, como ya hemos señalado en otro lugar, la paradoja central de la escritura de González radica en que su posterior programa antipoético con la propuesta extrema de formular una estética de la basura, de lo prohibido, de los restos, no pasa de ser sólo eso, una declaración de principios poéticos que nunca se traduce en práctica escrituraria (Ferrari, 2001: 128-167). Porque resulta incuestionable que la poesía de González, aún en aquellos libros en los que el juego, el humor, la irreverencia y el desenfado parecen poner en peligro el 'lirismo' de sus poemas, continúa siendo, en el sentido convencional de la expresión, una 'poesía poética'.

Además del tópico existencial y del tópico amoroso, despunta en este libro un incipiente planteo de índole autorreferencial, tres ejes que recorrerán toda la producción posterior del autor. En línea con lo que veníamos sosteniendo sobre el ethos de lo menor, con el poema "Me falta una palabra" se consolida, si bien en clave irónica, el perfil del poeta mendicante. La búsqueda es, en su inicio, tanteo en el vacío, aproximación a ciegas: "Me falta una palabra, una palabra / sólo [...] Una palabra dadme"; la pieza faltante en el ajedrez de algún soneto con rima difícil: "Una palabra dadme, una sencilla / palabra que haga juego / con...”. La actitud lúdica que guía este primer buceo en las posibilidades del

\footnotetext{
${ }^{4}$ Sin embargo, en este poemario coexiste la figuración amorosa de Oviedo tal como la leemos en el soneto "Capital de provincia" ("Ciudad de sucias tejas soleadas: / casi eres realidad, apenas nido", 2009: 43) con la reiterada mención de Madrid — "Aquí, Madrid, mil novecientos / cincuenta y cuatro"— y de Castilla — "Vengo de guerrear. / De guerrear por campos / de Castilla" o "Castilla —España— / sostiene mi tristeza / y frustrada espera"-, obligándonos a entender dichas menciones como enclaves deliberadamente ficcionalizados, si bien sabemos por datos de su biografía que en 1950 Ángel González marcha a Madrid para iniciar estudios de Periodismo.
} 
lenguaje cede paso a la estricta necesidad de una palabra única e irreemplazable — “esa palabra”-, palabra que se pretende sanadora: "La necesito: No véis / que sufro?”. Sin embargo la súplica acaba en fracaso: "Así no puedo" (2009: 19). La imposibilidad de hallar "la palabra" se vincula estrechamente con esa segunda voz en contrapunto, voz alter ego del sujeto que acarrea los componentes más degradados de la realidad histórico-social del yo: las "mujeres sucias con su lento llorar", los "miles de muertos", "el hombre ceniciento", "gente rota" que avasalla y anula toda posibilidad de escritura que no dé cuenta de eso mismo. Marcela Romano afirma lúcidamente que este texto "pone en escena una polaridad ideológica cifrada en el enfrentamiento entre una realidad urgida de soluciones y la indiferencia esteticista del sujeto-poeta" (2003: 53).

Resulta significativa la reiterada elección de la palabra "voz", con sus directas implicancias de oralidad para plasmar la reflexión metapoética en este libro. La suya es una voz que nace de la soledad y la tristeza y contagia igualmente de tristeza y soledad a aquello que nombra; la escritura es así un proceso autorreflejo que se vuelve tautológicamente sobre sí mismo: "Voz que soledad sonando / por todo el ámbito asola, / de tan triste, de tan sola, / todo lo que va tocando" (2009: 29) En otros poemas, la imposibilidad de dar salida a la palabra se metaforiza en el verso "Se me hiela la voz en la garganta" (2009: 43) que nos remite al taxativo anuncio de José Hierro: "No cantaré ya nunca más / El canto / se me ha secado en la garganta. / Se ha dormido en mi corazón / como una rosa" (1974: 286). El texto gonzaliano da cuenta del giro que sufre su escritura, el obligado abandono del poema amoroso por otro dominado por el desaliento: "Mi voz más dulce, con la que solía / hablar de amor a solas, se me enfría / aprisionando todo lo que canto" (2009: 45).

El ethos polémico que se muestra de modo incipiente en algunos poemas de este libro, como en el "Soneto a algunos poetas", irá adquiriendo perfiles mucho más acusados en libros posteriores. Juan Carlos Pueo estudia el funcionamiento de la ironía en este texto y afirma acertadamente que "la ironía toma forma de antífrasis estableciéndose a lo largo del texto dos posiciones contrapuestas para que el lector se identifique con aquella que el poeta considera más adecuada al oscuro período histórico en el que se ha visto inmerso" (2013: 113). Efectivamente, el sujeto pasa revista con una mirada profundamente crítica y una sanción descalificadora a la estética de los llamados 'poetas puros'. Aquí se juega con adjetivos — precisamente aquellos que califican a la lexía 'palabras' como "oscuras" y "puras" - que nos remiten a una práctica esteticista como la de Juan Ramón Jiménez o al hermetismo surrealista de algunos exponentes del '27: "Todas vuestras palabras son oscuras", leemos en el primer verso (2009: 46). Por su parte, una expresión como "serena palidez" nos reenvía a los sonetos clásicos de Garcilaso y a la depurada perfección de los seguidores de Jorge Guillén. Prácticas poéticas que se muestran a juicio del sujeto inoperantes y desprovistas de todo sentido. Pueo concluye:

El imperativo ético choca con la endeble torre de marfil en que se encierran estos poetas, y la echa abajo hasta dejar a esta clase de poesía desnuda hasta de sus propios fundamentos. La antífrasis hace que veamos impureza allí donde presuntamente se había afirmado lo contrario, y González dedicará el resto del poema a establecer un contraste entre las pretensiones de estos poetas y la imposibilidad de mantenerse al margen de las circunstancias (2013: 113). 
La construcción de un ethos irónico recorre todos los tópicos mencionados, el amoroso, el existencial y el autorreferencial. A partir de esta estrategia, la de la ironía, es que podemos advertir con mayor claridad el entrecruzamiento entre ethos discursivo y ethos autoral; así lo declara González:

La ironía facilita un tono de distanciamiento que aligera la peligrosa carga sentimental de ciertas actitudes, algo importante para una persona que, como yo, intenta escribir poesía desde sus experiencias conservando un mínimo de pudor. Impedir la pretenciosa formulación de las pretendidas verdades absolutas, introducir en la afirmación el principio de la negación, salvar la necesaria dosis de escepticismo que hace tolerables las inevitables — aunque por mi parte cada vez más débiles - declaraciones de fe: todo lo que la ironía facilita es lo que yo trataba de conseguir desde que comencé a escribir poesía [...]. Así, se explica mi fidelidad a unas fórmulas irónicas que, más que rasgos externos del poema, son en sí mismas una parte importante de lo que quiero expresar (2005: 410).

Ángel González sabía que "los poemas revelan mucho de la persona que los escribe” y como él mismo declara "por un elemental sentido del pudor hice esa poesía ambigua, o mejor dicho opaca, que no transparentaba mi sentimiento" (2005: 436-437). Cuando el poeta asturiano vincula el registro irónico con el pudor que busca "impedir la pretenciosa formulación de las pretendidas verdades absolutas", nos recuerda lo que Carl Dennis afirma en su ensayo:

[...] como lectores desconfiamos de los que se autoproclaman profetas, queremos que las voces poéticas no pretendan conocerlo todo. Si un hablante se dice completamente objetivo y realiza aseveraciones abstractas y categóricas, es muy probable que nosotros como lectores lo encontremos poco convincente (2001:15).

Efectivamente, más allá de la materia que trata, un poema triunfa en conmovernos porque nosotros aceptamos como sinceras y creíbles las credenciales retóricas de la voz que nos habla; el personaje poético se gana nuestro respeto y adhesión cuando nos hace creer en su modestia, en su humildad, en su integridad.

La acentuación elegíaca domina, como veíamos, la composición de este primer libro. Y son las reflexiones del propio autor las que nos ayudan a comprender mejor al sujeto de su escritura, al personaje poético:

Lo importante para ella —declara González acerca de su madre — era ser bueno y honesto. Es posible que en mi poesía haya quedado la nostalgia del mundo de bondad en el que creía mi madre, opuesto a una realidad donde esos valores no contaban demasiado. Probablemente esa decepción es lo que me lleve a hablar de las ruinas, los despojos, los escombros... Por supuesto que esas imágenes tienen que ver con el paso del tiempo, con el deterioro que el tiempo inevitablemente produce. Pero también pueden estar relacionadas con la nostalgia de una edad perdida, probablemente más imaginada que real, más soñada como perfecta que vivida como perfecta, y con la añoranza de la religión en la que me eduqué cuando niño, aunque ahora no soy nada religioso (González, 1990: 29).

Siempre más allá de los mandatos impuestos por las modas de las teorías literarias, Ángel González ha reconocido la existencia de un irrenunciable residuo biográfico en su escritura poética, apelando a la identificación final entre ethos discursivo y ethos autoral:

\footnotetext{
${ }^{5}$ Efectivamente, en el ámbito de la crítica anglosajona, dos son los aportes más relevantes sobre el tema del ethos. Me refiero al libro de Walter Nash, Retórica. El ingenio de la persuasión, de 1989, y al de Carl Dennis Poesía como persuasión, de 2001, ninguno de ellos traducidos al español.
} 
El atractivo ético de la poesía de Ángel González: a propósito de Áspero mundo

\begin{abstract}
Me temo que, aunque siempre sostengo lo contrario, estoy cayendo en la tentación de creer que el poeta que mis versos configuran ese personaje ilusorio que habla en los poemas soy efectivamente yo, y que el acabamiento del poeta significaría mi propio acabamiento...porque me resisto a confinar en el pasado ese residuo de mí mismo, a desprenderme de ese yo que es otro, pero que ahora cuando los dos estamos acercándonos a un final inevitable, noto que me hace muchísima compañía (1998: 35).
\end{abstract}

"El poema sin lector es inconcebible, no existe. El poema necesita al lector para ser, para terminarse, para hacerse del todo. En esta coincidencia de coautores del poema, el que en esta ocasión tiene menos que decir soy precisamente yo", con este énfasis afirmaba su postura Ángel González en 1987, y continuaba: "El autor del poema lo que hace es una propuesta, un texto; y esa propuesta o ese texto exige la respuesta del lector”. (Alarcos Llorach, 1987: 194). Efectivamente, al leer un poema, establecemos un contacto no sólo con un argumento o una opinión sino con todo un complejo de actitudes emocionales y éticas. Creo que el permanente atractivo ético que para nosotros, sus lectores, tiene la escritura de Ángel González es el que le imprime este carácter de su hablante, eco a su vez del autor que esta detrás de las palabras. Este ethos de lo menor comienza a configurarse, como vimos, en su primer libro bajo las metáforas de lo sobrante, del excedente, fragmento y sustancia desechable, nunca el centro sino los márgenes, poeta mendicante que clama por la limosna de una palabra. Un sujeto que se consolida en Tratado de urbanismo identificándose sistemáticamente con los perdedores de la historia, que descree de las grandes palabras y de las hazañas heroicas:

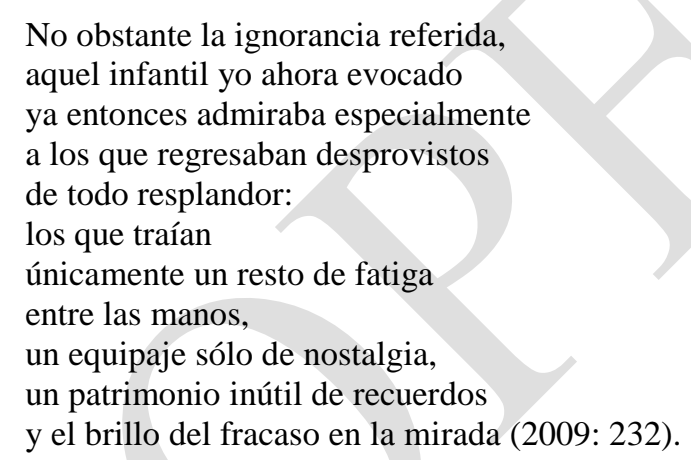

Y que finalmente se abisma con una mirada irónica hacia sí mismo en la escritura del poema titulado "Caída" con que se cierra Nada grave, su último libro:

Y me vuelvo a caer de mí mismo

al vacío,

a la nada.

¡Qué pirueta!

¿Desciendo o vuelo?

No lo sé.

Recibo

el golpe de rigor, y me incorporo.

Me toco para ver si hubo gran daño,

mas no me encuentro.

Mi cuerpo, ¿dónde está?

Me duele sólo el alma.

Nada grave (2008: 73). 
Tanto en su discurso poético como en sus escritos paratextuales, Ángel González construye un ethos que es sostenidamente el mismo, el del "poeta menor". En la contraportada del libro que reúne la casi totalidad de su obra poética, Palabra sobre palabra, publicada por Seix Barral en 2009, leemos una nota autobiográfica del autor. En ella se nos presenta como 'testigo' - antes que actor- de los acontecimientos políticos que cifraron su vida, 'súbdito' de un rey, 'objeto' de una tiranía, un sujeto pasivo y dócil, - "disciplinado y recto" dirá en uno de sus poemas más significativos— "zarandeado por el destino que urdió su trama sin contar nunca con su voluntad", que se "resigna" a estudiar la carrera de Leyes, norma de "obligado cumplimiento a la que me sometî", datos todos de una biografía que resulta replicada en su práctica escrituraria: una queja en voz baja, una tonalidad sin énfasis ni estridencias, una cierta reticencia en el decir, un tono próximo al lector, una poesía, en síntesis, de tono menor que apela al distanciamiento irónico como forma de enmascarar el sentimentalismo, es decir de preservar el núcleo duro de la intimidad (el pathos de la retórica clásica entendido como un afecto que arrebata violentamente el ánimo del oyente), y que se vuelca decididamente hacia la apuesta ética más que a la patética.

Pero es también Ángel González quien declara que:

[...] pese a todas las limitaciones —enormes - que derivan de esas circunstancias (la guerra), aprendimos muchas cosas importantes; a decir no (en voz baja, por supuesto, pero con inquebrantable terquedad); a no darnos nunca por vencidos a pesar de sabernos derrotados (...); a mantener vivo el espíritu de subversión bajo la costra de la sumisión (2009).

De hecho en el poema ya citado, "Para que yo me llame Ángel González", el sujeto se autodefine como "escombro" pero ese escombro es "tenaz", "se resiste a su ruina", "lucha contra el viento" y "avanza por caminos que no llevan a ningún sitio". Una firmeza de actitud -tenacidad, terquedad, resistencia - que sobrevive a toda su obra poética como bien lo demuestra el título de su segundo poemario: Sin esperanza, con convencimiento.

Quintiliano traducía el concepto griego de ethos como "costumbre o hábito del alma" (1916: 320-327), y efectivamente, es ese sentido de habitualidad en un modo de ser, en una manera de estar en el mundo y, sobre todo, de presentarse ante el lector a través de su escritura el que configura el carácter del hablante gonzaliano. Quiero concluir con unas declaraciones de su amigo y poeta Luis García Montero quien realiza una excelente síntesis de esto que aquí venimos señalando cuando afirma:

Después de sufrir su guerra, de recorrer los prados y las calles de sus quimeras infantiles, de respirar el aire espeso de una adolescencia contaminada por los himnos, las delaciones y el bacilo de Koch, comprenderán mejor el tono bajo con el que hablaba de las cosas altas, el humor que utiliza para acercarse a los asuntos demasiado serios (2009: 43). 


\section{Bibliografía}

AlarCos LlORACH, Emilio (1987): La poesía de Ángel González. Oviedo, Nobel.

Amossy, Ruth (2010): «Images de soi, images de l'autre. 'Je'- 'Tu'», en La présentation de soi. Ethos et identité verbale, París, Presses Universitaires de France, pp. 103-130.

ARISTÓTELES (1971): Retórica. Trad. Antonio Tovar. Madrid, Instituto de Estudios Políticos.

BALlART, Pere (2005): "Una elocuencia en cuestión o el ethos contemporáneo del poeta", Signa: Revista de la Asociación Española de Semiótica, 14, pp. 73-104; en http://descargas.cervantes virtual.com/servlet/SirveObras/91383841878605943754491/029207.pdf?incr=1 (última consulta, 7-1-2017).

CAFFARATO, Mauro (2008): “La importancia de llamarse Ángel González”, Cuadernos Hispanoamericanos, 17, pp. 84-97.

CASAS, Arturo (2000): “Topografía de una niebla. Sentido del lugar en Cuaderno en Nueva York", en Sara PujOL y Julia UCEDA, coords., José Hierro: mi voz en la voz de los otros. Ferrol, La Barca de Loto, pp. 53-63.

Dennis, Carl (2001): Poetry as Persuasion, an Essay for Writers. Athens, University of Georgia Press. FERRARI, Marta Beatriz (2001): La coartada metapoética. José Hierro, Ángel González, Guillermo Carnero. Mar del Plata, Martin.

FERRATÉ, Joan. (1968): Dinámica de la poesía: ensayos de explicación, 1952-1966. Barcelona, Seix Barral.

GARcíA Montero (2009): Mañana no será lo que dios quiera. Madrid, Alfaguara.

GONZÁLEZ, Ángel (1990): “Autopercepción intelectual de un proceso histórico”, Anthropos, 109, pp. 19-29.

(1998): Revista El País, domingo 11 de enero de 1998, pp. 35.

- (2005): La poesía y sus circunstancias. Ed. de José Luis García Martín. Barcelona, Seix Barral.

- (2008): Nada grave. Madrid, Visor.

- (2009): Palabra sobre palabra. Obra completa (1956-2001). Barcelona, Seix Barral.

Hierro, José (1974): Cuanto sé de mí. Barcelona, Seix Barral.

MANGONE, Carlos - WARLEY, Jorge (1994): El manifiesto. Un género entre el arte y la política, Buenos Aires, Biblos.

PuEO, Juan Carlos (2013): “Espía de palabras: Ironía y poética de Ángel González”, en Túa BLESA, Juan Carlos Pueo, Alfredo Saldaña y Enric Sullà, eds., Pensamiento literario Español del Siglo XX, 3, Zaragoza, Anexos de Tropelías, pp. 125-146.

QuintILIANO (1916): Instituciones oratorias. Trad. Ignacio Rodríguez y Pedro Sandier. Madrid, Imprenta de Perlado Páez y Compañía.

Romano, Marcela (2003): Almas en borrador. Sobre la poesía de Ángel González y Jaime Gil de Biedma. Mar del Plata, Martin.

Smith, Craig R. (2004): "Ethos dwells pervasively. A hermeneutic reading of Aristotle on credibility", en Michael J. HydE, ed., The ethos of rhetoric. Columbia, University of South Carolina. 
380 | Tropelías. Revista de Teoría de la Literatura y Literatura Comparada, 29 (2018) Marta Beatriz Ferrari

SOURIAU, Ettiene (1933): “Art et verité", Revue Philosophique de la France et de l'Etranger, 115, pp. 161-201.

SPANG, Kurt (2005): Persuasión. Fundamentos de retórica. Pamplona, Universidad de Navarra.

VillanueVA, Tino (1988): "Primeros tanteos: contemplación lírica y realidad histórica en Áspero mundo (1956)", en Tres poetas de posguerra: Celaya, González y Caballero Bonald (Estudio y entrevistas). Madrid, Tamesis. 